\title{
FLEXICURITY POLICIES AND THEIR ASSOCIATION WITH PRODUCTIVITY IN THE EUROPEAN UNION
}

\author{
Primož Dolenc, Suzana Laporšek*
}

\begin{abstract}
:
The paper examines the issue of flexicurity in the EU Member States and studies the association between flexicurity policy components (i.e. employment protection legislation, lifelong learning programs, active and passive labour market policies) and labour and total factor productivity growth in 20 EU Member States over the 1991-2008 period. The empirical analysis pointed on the existence of large differences in the level of implementation of flexicurity policies across EU Member States, by which the least successful are NMS, especially with regard to active labour market and lifelong learning programs. As regards the relation between flexicurity variables and productivity growth, panel regression estimates showed that active labour market policies and participation in lifelong learning programs have a statistically significant positive association with labour and total factor productivity growth. On the other hand, rigid employment protection and high expenditures for passive labour market policies negatively relate to productivity growth.
\end{abstract}

Keywords: flexicurity, labour market, productivity, European Union

JEL Classification: J08.

\section{Introduction}

The concept of flexicurity promotes the idea of finding the right balance between flexible employment arrangements and security of workers on the labour market. Flexicurity therefore suggests that flexibility and security should not be perceived as mutually exclusive but as complementary. From the viewpoint of the European Commission, it is an important tool for increasing labour market competitiveness in light of globalization and labour market challenges and for enhancing workers' employment security (see European Expert Group on Flexicurity, 2007). Flexicurity approach can be designed and implemented across four policy components: (i) flexible and reliable contractual arrangements; (ii) lifelong learning programs; (iii) active labour market policies; and (iv) social security (European Commission, 2007a).

This paper aims to examine the concept of flexicurity as perceived in the European Union (EU), to give an overview of the implementation situation of flexicurity policies across the EU Member States and to assess the relationship between flexicurity components

* UP Faculty of Management Koper, Cankarjeva 5, p.p. 345, SI-6101 Koper, Slovenia (primoz. dolenc@fm-kp.si; suzana.laporsek@fm-kp.si). 
and productivity. As flexicurity policies are complex, we focus our analysis on four representative labour market variables, one for each flexicurity component (used also by the European Commission, 2007a): Employment Protection Legislation (EPL) index, participation rate in lifelong learning (LLL) programs, and expenditures for active and passive labour market policies (ALMPs and PLMPs, respectively). ${ }^{1}$ In order to present performance of the EU Member States in implementing flexicurity approach we rely on descriptive statistics for year 2008, i.e. before the peak of economic crisis. To estimate relations between flexicurity components and productivity growth measures we employ panel regression analyses performed on data for $20 \mathrm{EU}$ Member States over the 1991-2008 period.

The rest of the paper is organized as follows. Section 2 briefly explains the flexicurity concept, followed by an overview of empirical studies on the relationship between representative flexicurity variables and productivity in Section 3. Section 4 presents methodology and data. Section 5 is devoted to the presentation of results of the empirical analysis. Section 6 concludes.

\section{The Concept of Flexicurity}

The notion of flexicurity presents an oxymoron that combines two concepts (flexibility and security) that were previously seen in opposition. It was first employed in the context of labour market reforms in the Netherlands during the mid-1990s. The latter resulted in two legal acts, i.e. the Flexibility and Security Act and the Act concerning the Allocation of Workers via Intermediaries, which aimed to ease the dismissal rules and rules concerning temporary work agencies, and to provide for higher level of security for workers in flexible jobs (see Keune, Jepsen, 2007; Wilthagen, Tros, 2004). Although flexicurity as a labour market policy has been initiated in the Netherlands, it is today often associated with the Danish labour market. The Danish "golden triangle" namely presents a prime example of a well-functioning flexicurity arrangement. It combines flexible labour market (i.e. high degree of occupational and geographical job mobility due to low employment protection), high social security (i.e. generous system of unemployment benefits, UBs) and ALMPs aimed at skill improvement and activation of unemployed. ${ }^{2}$

Flexicurity is today in the core of academic and political debate about labour market reforms, nevertheless, it remains ill defined. The most widely used definition comes from Wilthagen, Tros (2004, p. 14) who define flexicurity as “... a policy strategy that

1 As the institutional variables for generosity of income replacement during unemployment were not available for the entire studied period, we use expenditures for PLMPs as a proxy for unemployment benefits (UBs) generosity. Namely, our analysis showed that countries with higher expenditures for PLMPs, on average, provide higher income replacement during unemployment (relation is statistically significant at $5 \%$ level of significance); results are available on request.

2 Although the Danish golden triangle is a successful model of flexicurity, this is not the guarantee that the same model would also be effective in other countries. A review of possible reasons why implementation might fail in other countries is available in de Groot, Elhorst (2010) and Algan, Cahuc (2006). 
attempts, synchronically and in a coordinated way, to enhance the flexibility of labour markets, the work organization and labour relations on the one hand, and to enhance security - employment security and social security - notably for weaker groups in and outside the labour market on the other hand. "As this definition understands flexicurity mostly as a deliberate political choice, they introduced an additional definition, which refers to flexicurity as a state of affairs, i.e. including a degree of job, employment, income and combination security, and a degree of numerical, functional, and wage flexibility. Third understanding of flexicurity is as analytical tool appropriate to analyse flexibility and security developments and to compare national labour market systems (Bredgaard, Larsen, 2007; Madsen, 2007).

Probably the main reason why flexicurity has become one of the key labour market concepts is its adoption and promotion by the European Commission. The search for balance between flexibility and security is especially evident within the European Employment Strategy as, according to the Council of the EU (2003), flexicurity presents a toll that would positively affect competitiveness of firms, enhance quality and productivity at work and facilitate adjustment of employers and employees to economic changes. To encourage the adoption of the flexicurity approach by the Member States, the European Expert Group on Flexicurity in 2007 presented four pathways on flexicurity: i) tackling contractual segmentation; ii) developing flexicurity within enterprises and offering transition security; iii) tackling skills and opportunity gaps among the workforce; and iv) improving opportunities for benefit recipients and informally employed workers. In the same year, the European Commission (2007a) translated pathways into four policy components:

1. flexible and reliable contractual arrangements, both for employers and employees, ensured through modern labour laws and work organization;

2. comprehensive LLL strategies to address the challenges of rapid technological development and innovation in order to keep up productivity and competitiveness of firms, and long-term employability of workers;

3. effective active employment policies to help people to cope with rapid change, facilitate transitions to employment and improve the efficiency of job matching;

4. modern social security systems that provide for adequate UBs to act as a safety net during job changes, however, not pulling people out of the labour market.

European Commission (2007b) stresses that crucial preconditions for effective implementation of flexicurity approach are involvement of all social partners and well-established social dialogue. Moreover, flexicurity should be pursued in a wider context of sound macro- and microeconomic policies and embedded in a wider framework of labour market regulation and employment rights (European Expert Group on Flexicurity, 2007). At this point it should be also noted that every country has to shape its own approach to flexicurity. 


\section{Flexicurity Components and Productivity - Overview of Empirical Studies}

Employment protection regulations, as the first flexicurity component, have theoretically ambiguous effects on productivity. Strict EPL can aggravate dismissal of workers, making it more difficult for firms to react quickly to changes in technology or product demand (Hopenhayn, Rogerson, 1993; Saint-Paul, 1997, 2002; Poschke, 2009), discouraging them from experimenting with new technologies (Bartelsman et al., 2005) and reducing effort of workers (Ichino, Riphahn, 2005). Moreover, it may decrease firms' business expectations, reducing their willingness to employ (Stubelj, 2010). All these can negatively affect productivity. On the other hand, Soskice (1997) and Belot et al. (2007) derived opposite predictions. Assuming that strict dismissal regulations provide additional job security for workers and thus increase job tenure and work commitment, firms and workers are more likely to invest in firm- or job-specific human capital, with expected positive impact on productivity.

The empirical evidence on the relation between EPL and productivity is also mixed. Exploiting firm-level data, Autor et al. (2007) showed that adoption of wrongfuldischarge protections in the United States decreased total factor productivity (TFP), by which the effects were strongest in the short run. Namely, adoption of dismissal protections altered short-run production choices and caused that employers retained unproductive workers, resulting in a reduced technical efficiency. About similar findings for Italian firms reported also Cingano et al. (2010). Micco and Pages (2006) found a negative relationship between dismissal costs and labour productivity (LP) using data for manufacturing sector in 18 countries, yet results were biased due to presence of Nigeria in the sample. Furthermore, Scarpetta and Tressel (2004) showed that strict EPL has a significant negative impact on productivity only in countries with an intermediate degree of centralization/coordination in wage bargaining. Significant, yet small negative effect of EPL index on TFP was confirmed also by Bassanini and Venn (2008) and Bassanini et al. (2009), by which they estimated that the effect is stronger in industries where the need for labour reallocation is higher. On the other hand, Nickell and Layard (1999) and Koeniger (2005) showed a weak positive relationship between EPL and LP and TFP growth for OECD countries.

As regards the second flexicurity component, LLL, literature mostly focuses on the productivity effects of training. In this sense, several studies reported about a positive relation between training and productivity. For instance, Black and Lynch (1996) showed that a $10 \%$ increase in education raised productivity for $4.9 \%$ in manufacturing and $5.9 \%$ in non-manufacturing sector in the United States. Similarly, Bishop (1994) found that formal training received on the job from a previous employer increased initial productivity by $9.5 \%$ of the wage, whereas formal training received off the job increased current productivity by $15.9 \%$. Moreover, on the panel of British industries between 1983 and 1996, Dearden et al. (2006) found that a $1 \%$ increase in training is associated with an increase in value adder per hour of about $0.6 \%$. The overview of early studies on this issue is available also in Machin, Vignoles (2001). 
ALMPs aim to enhance employability and productivity of workers by increasing human capital and improving their skills. ${ }^{3}$ Yet, the ALMPs effects on productivity were subjected to less research. OECD (1999) showed that ALMPs could raise LP, yet this effect may be also associated with an increase in employment and wages. Similar findings were obtained by Calmfors (1994), who noted that ALMPs positively affect productivity, resulting in an increase of employment at a given wage rate. However, he claimed that an increase in productivity is not self-evident because it is possible to produce the same output with fewer but more efficient workers. Parello (2011), in addition, showed that ALMPs could increase employment with positive effects on long-run productivity growth also through an increase in the innovation rate.

UBs, a measure of the fourth flexicurity component, may affect productivity through various channels ( see OECD, 2007). Positive association between UBs and productivity is expected through their impact on employment, especially by improving job-match quality (Marimon, Zilibotti, 1999) and by encouraging the creation of high-productivity, high-risk jobs (Acemoglu, Shimer, 1999, 2000; OECD, 2007). On the other hand, generous UBs can decrease productivity due to increase of unemployment spells and lower opportunity costs of unemployment (see OECD, 2007).

\section{Methodology and Data}

Lack of common definition and an all-embracing indicator of flexicurity might be the reason why most of other papers focus on the theoretical aspects of flexicurity, leaving a lot of room for empirical research. In the continuation we examine the association between productivity and the following representative flexicurity labour market variables: (1) EPL index to present flexibility of contractual arrangements; ${ }^{4}$ (2) participation of adults in LLL programs; (3) government expenditures for ALMPs; and (4) government expenditures for PLMPs as a proxy of generosity of income replacement policies during unemployment. Variables to represent the flexicurity components were chosen from the list of the European Commission (2007a).

First part of the empirical analysis is devoted to an overview of the attainment of flexicurity objectives across the EU Member States. At the same time, we search for potential correlations between chosen flexicurity variables and LP level (i.e. GDP per hour worked, in USD PPP). Analysis is performed using data for 2008, i.e. before the peak of the economic crisis. ${ }^{5}$

3 Intangible factors are deemed to be the fundamental source of competitive advantages in today's knowledge economy (Jerman et al., 2010).

4 EPL index covers three aspects of employment protection: (i) individual dismissal of regular workers; (ii) regulation of temporary contracts; and (iii) additional costs for collective dismissals. Until today OECD presented three methodologies of the EPL index calculation. We base our analysis on the first version of the EPL index (see OECD, 2011).

5 At the same time we analyse potential differences between old and New EU Member States (NMS) using Mann-Whitney non-parametric test (a non-parametric test was used due to small sample of countries). 
We continue our empirical analysis with the estimation of the relationship between above listed flexicurity variables and LP and TFP growth. Relations were estimated using panel regression analysis, performed on the sample of 20 EU countries over the 1991-2008 period. ${ }^{67}$ The basic regression function had the following specifications:

$$
X_{i, t}=\alpha_{0}+\Psi\left[\begin{array}{l}
\ln E P L_{i, t} \\
\ln L L L_{i, t} \\
\ln A L M P_{i, t} \\
\ln P L M P_{i, t}
\end{array}\right]+\Pi\left[\begin{array}{l}
\ln T W_{i, t} \\
\ln T U D_{i, t} \\
\ln G D P p c_{i, t} \\
\ln L U R_{i, t}
\end{array}\right]+\varepsilon_{i, t},
$$

where $X_{i, t}$ denotes LP growth and TFP growth in subsequent regression analyses. $E P L$ refers to overall EPL index in country $i$ at time $t, L L L$ to participation in lifelong learning programs, $A L M P$ denotes expenditures for active labour market programs, whereas PLMP expenditures for passive labour market programs (both in $\%$ of gross domestic product (GDP)). In order to control for labour market situation, we also include tax wedge $(T W$ ) for single person without children earning $2 / 3$ of average wage as a measure of labour taxation, trade union density (TUD) as a measure of trade union's presence and long-term unemployment rate $(L U R)$. As a control variable of macroeconomic environment we use GDP per capita (GDPpc) in USD PPP. $\Psi$ and $\Pi$ are vectors of regression coefficients measuring, respectfully, the association of productivity growth measures with explanatory variables and control variables.

We re-estimated the above regression function by including year dummies (vector $Y$ ) in order to control for effects that may influence all countries in a given year in the same way (for example, world-wide shocks):

$$
X_{i, t}=\alpha_{0}+\Psi\left[\begin{array}{l}
\ln E P L_{i, t} \\
\ln L L L_{i, t} \\
\ln A L M P_{i, t} \\
\ln P L M P_{i, t}
\end{array}\right]+\Pi\left[\begin{array}{l}
\ln T W_{i, t} \\
\ln T U D_{i, t} \\
\ln G D P p c_{i, t} \\
\ln L U R_{i, t}
\end{array}\right]+\Upsilon\left[\begin{array}{l}
\text { Year 1991 } \\
\vdots \\
\text { Year 2008 }
\end{array}\right]+\varepsilon_{i, t} .
$$

In addition, relations between flexicurity policies and productivity growth measures were (across different model specifications) estimated both using fixed and random effects. Doing this we tried to avoid biases that could arise from different estimations

6 The panel included Austria, Belgium, the Czech Republic, Denmark, Estonia, Finland, France, Germany, Greece, Hungary, Ireland, Italy, the Netherlands, Poland, Portugal, Slovakia, Slovenia, Spain, Sweden, and the United Kingdom. Other EU Member States were left out due to the lack of data.

7 Decision on the length of studied period was motivated by i) the availability of data; ii) the fact that going further back in the past would not bring clear results for most of the NMS due to changes in their political and economic situation. 
methodologies (see Wooldridge, 2002). ${ }^{8}$ All regression models were controlled for heteroskedacity and autocorrelation using robust standard errors. ${ }^{9}$

Data needed for empirical analysis were obtained from the OECD.Stat database (2011), Eurostat (2011) and the Conference Board database (2011). Missing estimations for EPL index for 1991-2004 period for Slovenia were obtained from Vodopivec et al. (2007), whereas for Estonia from Muravyev (2010). Missing historical time series for expenditures for ALMPs, PLMPs and labour taxation of average worker were collected from the CEP-OECD institutions dataset (Nickell, 2006). Time series data for trade union density were obtained from Visser (2011). ${ }^{10}$

\section{Results of the Empirical Analysis}

\subsection{The level of implementation of flexicurity components across the EU Member States}

\section{Employment protection legislation}

As can be seen from Figure 1, differences in the rigidity of employment regulations among the EU Member States are substantial. Employment legislation is at most flexible in the Anglo-Saxon countries, followed by Nordic countries, and becomes more rigid when moving to the Southern EU Member States (see Laporšek and Dolenc, 2012). Similarly, countries differ in the level of LP per hour worked, being especially low among the NMS. Regarding the association between rigidity of EPL and LP, scatterplot indicates a potentially negative relation between EPL strictness and LP growth, however linear regression coefficient is statistically insignificant.

8 The estimates of Hausman test showed that fixed effects models (with one exception) are more appropriate for analysis (see Table 1).

9 The presence of heteroskedacity and autocorrelation was confirmed by likelihood-ratio test and Wooldrige test, respectively. Statistics can be obtained from the authors.

10 Missing data on participation of adults in LLL programmes in NMS within the 1991-1998 period were calculated using the trend line evaluation techniques. 
Figure 1

Strictness of EPL and LP per Hour Worked, EU, 2008

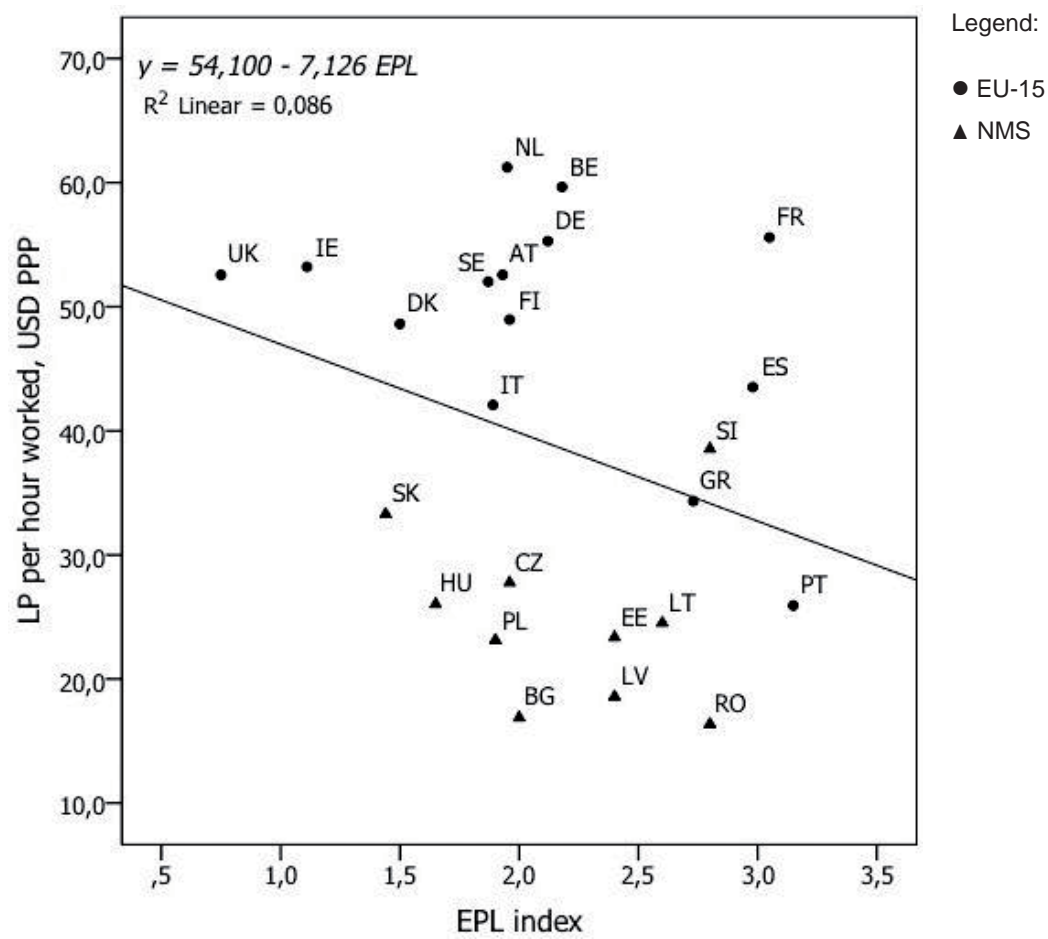

Source: authors' calculations.

\section{Lifelong learning}

Data on participation of adults in LLL programs show that there is a large gap in implementation of these programs across the EU countries. On one side, participation rates exceed 20\% in Nordic countries and expand even to $30 \%$ in Denmark. On the other, participation is the poorest in Eastern and Baltic NMS, which hardly achieve $5 \%$ participation rate, probably reflecting a lack of awareness and investments in LLL before and during the transition period. ${ }^{11}$ Yet, it is of immense importance for NMS to strengthen their LLL programs. Namely, as can be seen from Figure 2, participation in LLL programs positively associates with LP per hour worked, signifying that implementation of LLL programs and their effective usage could through improving workers' knowledge and skills stimulate the LP of workers and by that induce their employability.

11 In average, the participation rate in LLL programs in EU-15 is $12.5 \%$, whereas in NMS-12 5.9\% in 2008 (the difference between groups of countries is statistically significant at $5 \%$ significance level). 
Figure 2

Participation Rate in LLL Programs and LP per Hour Worked, EU, 2008

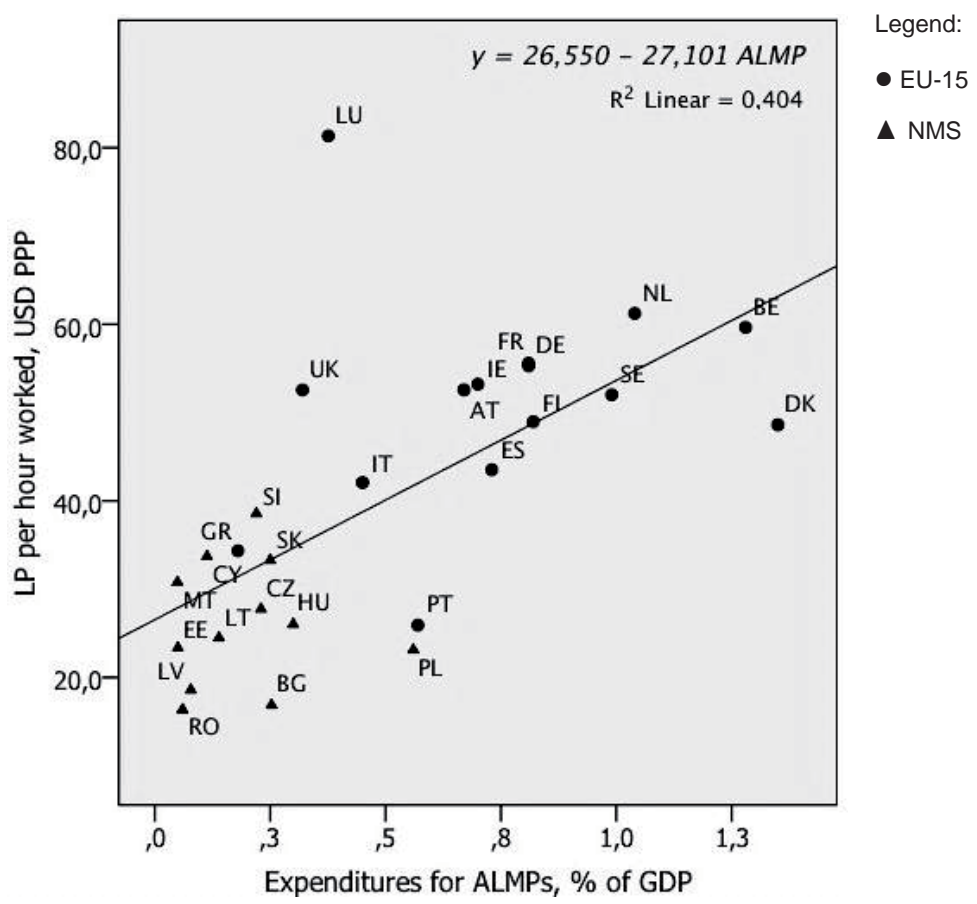

Source: authors' calculations.

\section{Active labour market policies}

ALMPs aim to enhance human capital, to ensure employability of workers and to facilitate unemployment-employment transitions. Irrespective of its importance, government expenditures for ALMP are still low, especially in NMS. For comparison, in 2008 old EU Member States, on average, earmarked $0.74 \%$ of GDP (or $0.14 \%$ of GDP per 1 percentage point of unemployment), whereas NMS only $0.19 \%$ of GDP (or $0.03 \%$ of GDP per 1 percentage point of unemployment). ${ }^{12}$ The share of ALMPs expenditures in all expenditures for labour market programs is rather low, as it amounts, on average, $42 \%$. Furthermore, as shown in Figure 3, countries with higher expenditures for APLMs record higher levels of LP per hour worked and vice versa, suggesting that ALMPs might stimulate productivity.

12 The difference between groups of countries is statistically significant at $5 \%$ significance level. 


\section{Figure 3}

Expenditures for ALMPs (as \% of GDP) and LP per Hour Worked, EU, 2008

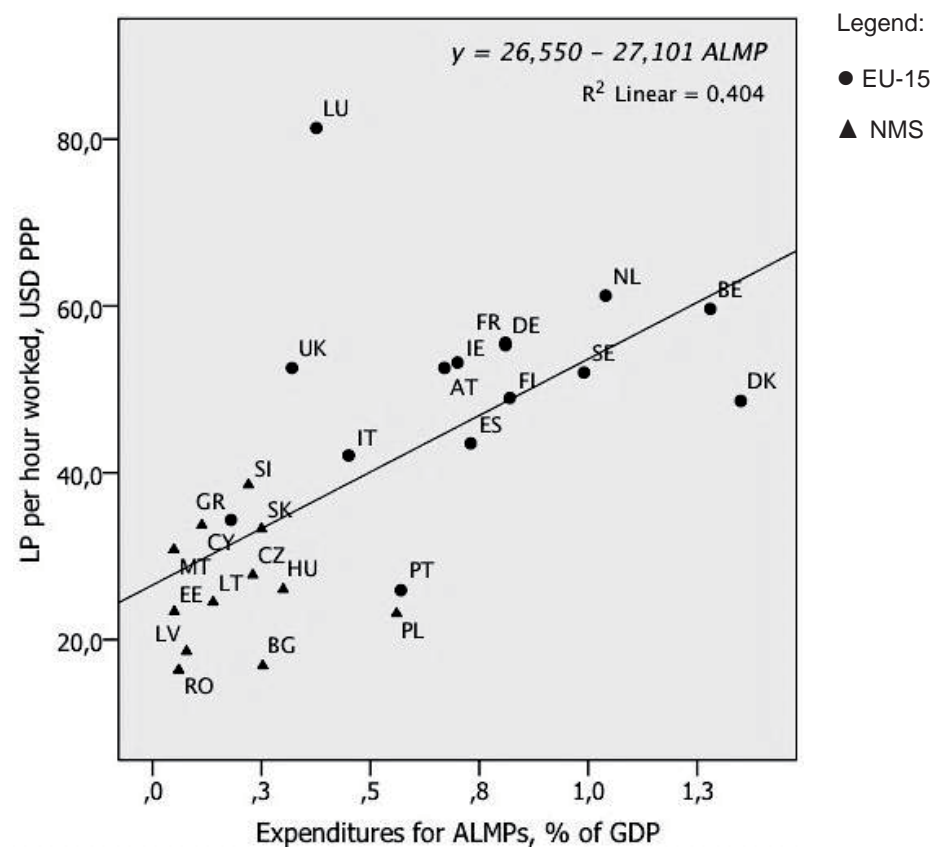

Source: authors' calculations.

\section{Passive labour market policies and unemployment benefits}

UBs, together with early retirement schemes, classify under the PLMPs. ${ }^{13}$ Expenditures for PLMPs are, similarly as for ALMPs, the most generous in Nordic countries along Belgium, Germany and Spain. On the other hand, the lowest expenditures can be found among NMS. Again, countries that record higher expenditures for PLMPs attain higher productivity levels (see Figure 4(a)). Nevertheless, this association may be doubtful from a theoretical perspective and may be a consequence of reverse causality - richer countries that achieve high productivity levels can afford higher expenditures for PLMPs. ${ }^{14}$

One of the common measures of UBs generosity is also net replacement rate (NRR), ${ }^{15}$ which measures the effect of the move from employment to unemployment on household incomes. On average and irrespectively the family type, NRR (in the first unemployment

13 As the data on the share of PLMPs devoted to UBs are not available for the entire studied period, we present data on total expenditures for PLMPs.

14 We find in the analysis that countries with higher GDP p.c. PPP have higher expenditures for PLMPs (relation is statistically significant at $5 \%$ level of significance); results are available on request.

15 NRR is defined as a ratio of net income while out of work and net income while in work (see Dolenc and Vodopivec, 2005). 
year) is smaller for those with higher pre-unemployment wage, meaning that when moved to unemployment those with the lowest pre-unemployment wage (financially) lose the least. On average, at the EU level, those with pre-unemployment wage at the level of $67 \%$ lost $30 \%$ of previous income in 2008, whereas those with pre-unemployment wage at the level of $150 \%$ lost almost $40 \%$ or $50 \%$ of previous income. As can be seen from Figure 4(b), the NRR is the highest among Nordic and some continental countries along some of the NMS. Regarding the duration of UBs, NMS mostly provide benefits up to maximum duration of 12 months (with exception of Slovenia), whereas, on average, the possible entitlement to UBs lasts longer, in Belgium even indefinitely.

Figure 4

Expenditures for PLMPs (a) and NRR for First Year of Unemployment (b) vs. LP per Hour Worked, EU, 2008

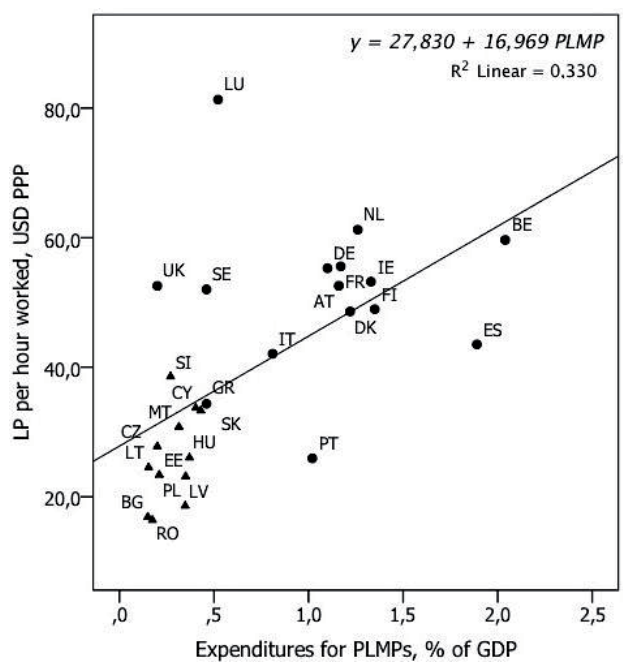

(a)

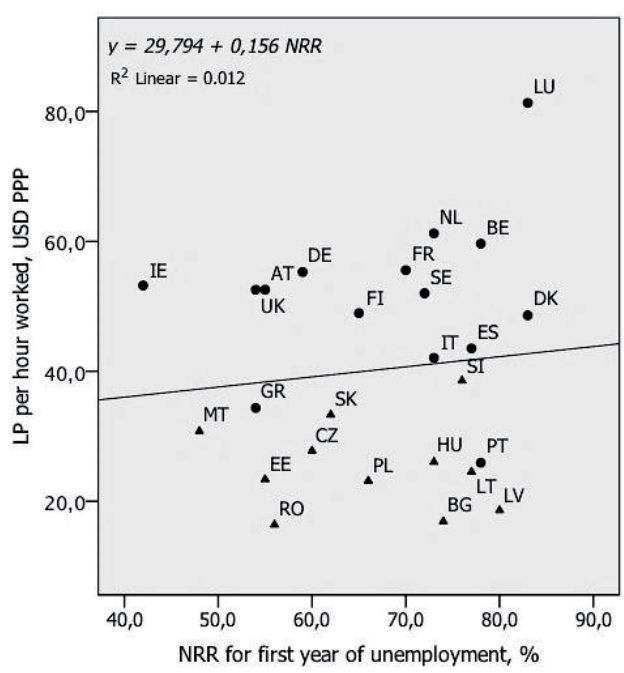

(b)

Legend:

EU-15;

$\Delta$ NMS.

\section{Source: authors' calculations.}

\subsection{Estimation of relations between flexicurity components and productivity growth}

In this section we extend previously performed descriptive statistics and with the use of panel regression methods analyse relations between chosen flexicurity variables and both LP growth (i.e. change in the level of LP per hour worked) and TFP growth. Analysis was conducted on the panel of 20 European countries during 1991-2008 period. Estimation results are summarized in Table 1. 
Table 1

Estimation Results of the Panel Regression Analysis

\begin{tabular}{|c|c|c|c|c|}
\hline \multirow[b]{2}{*}{ Model } & \multicolumn{2}{|c|}{ LP growth } & \multicolumn{2}{|c|}{ TFP growth } \\
\hline & (1) & (2) & (4) & (5) \\
\hline \multicolumn{5}{|c|}{ Fixed (within group) effects } \\
\hline Constant & $72.62^{*}(37.80)$ & $56.56 \quad(46.09)$ & $-0.72 \quad(24.72)$ & $4.92 \quad(25.51)$ \\
\hline InEPL & $-0.38 \quad(1.07)$ & $-0.76 \quad(1.17)$ & $-0.45 \quad(0.86)$ & $-0.89(1.02)$ \\
\hline InLLL & $0.81 \quad(0.84)$ & $0.77 \quad(0.95)$ & $0.32 \quad(0.46)$ & $0.13 \quad(0.52)$ \\
\hline InALMP & $2.20^{* *}(0.90)$ & $1.89^{* *}(0.83)$ & $1.70^{* *}(0.53)$ & $1.50^{* *}(0.52)$ \\
\hline InPLMP & $-0.76 \quad(0.76)$ & $-0.65 \quad(0.73)$ & $-0.98 \quad(0.57)$ & $-0.77 \quad(0.47)$ \\
\hline InTW & $-4.52^{*} \quad(2.35)$ & $-3.25 \quad(2.69)$ & $-0.79 \quad(1.82)$ & $-0.20 \quad(2.22)$ \\
\hline InTUD & $-3.32^{\star *} \quad(1.12)$ & $-3.93^{* *}(1.23)$ & $0.79 \quad(0.83)$ & $-0.19 \quad(0.79)$ \\
\hline InGDPpc & $-4.29 \quad(2.77)$ & $-2.97 \quad(3.50)$ & $0.02 \quad(1.92)$ & $-0.35 \quad(1.94)$ \\
\hline InLUR & $1.63^{* *}(0.51)$ & $1.03^{*}(0.53)$ & $1.92^{* \star}(0.64)$ & $1.27^{\star} \quad(0.66)$ \\
\hline$R^{2}$ - overall & 0.10 & 0.11 & 0.10 & 0.19 \\
\hline $\mathrm{R}^{2}-$ within & 0.23 & 0.31 & 0.16 & 0.30 \\
\hline$R^{2}$ - between & 0.05 & 0.10 & 0.01 & 0.02 \\
\hline \multicolumn{5}{|c|}{ Random effects GLS } \\
\hline Constant & $23.88^{* *} \quad(10.92)$ & $17.40^{\star} \quad(10.35)$ & $16.16^{*} \quad(9.36)$ & $12.70 \quad(11.26)$ \\
\hline InEPL & $-0.29 \quad(0.50)$ & $-0.37 \quad(0.51)$ & $-0.26 \quad(0.49)$ & $-0.47 \quad(0.49)$ \\
\hline $\operatorname{lnLLL}$ & $0.90^{* *} \quad(0.35)$ & $0.86^{* *} \quad(0.37)$ & $0.75^{* *} \quad(0.31)$ & $0.61^{*} \quad(0.34)$ \\
\hline InALMP & $1.34^{* *}(0.52)$ & $1.13^{* *}(0.51)$ & $1.09^{* *}(0.41)$ & $0.96^{* *}(0.38)$ \\
\hline InPLMP & $-1.16^{\star \star} \quad(0.39)$ & $-1.13^{* *}(0.41)$ & $-0.94^{* *}(0.37)$ & $-0.85^{\star *}(0.39)$ \\
\hline InTW & $-1.35(1.03)$ & $-0.95 \quad(1.04)$ & $-0.35 \quad(1.07)$ & $0.06 \quad(1.02)$ \\
\hline InTUD & $-0.56 \quad(0.38)$ & $-0.84^{* *}(0.37)$ & $0.18 \quad(0.36)$ & $-0.17 \quad(0.35)$ \\
\hline InGDPpc & $-1.69^{* *}(0.76)$ & $-1.20 \quad(0.92)$ & $-1.67^{\star *}(0.80)$ & $-1.37 \quad(0.99)$ \\
\hline InLUR & $1.67^{\star *}(0.38)$ & $1.36^{* *}(0.38)$ & $1.52^{* *}(0.35)$ & $1.15^{\star \star}(0.35)$ \\
\hline$R^{2}$ - overall : & 0.15 & 0.23 & 0.17 & 0.30 \\
\hline$R^{2}-$ within & 0.19 & 0.27 & 0.15 & 0.29 \\
\hline $\mathrm{R}^{2}$ - between & 0.23 & 0.22 & 0.33 & 0.36 \\
\hline Year dummies & No & Yes & No & Yes \\
\hline Hausman test & $53.62^{* *}$ & $49.59^{* \star}$ & $16.59^{\star *}$ & 12.35 \\
\hline No. of obs. & 359 & 359 & 354 & 354 \\
\hline
\end{tabular}

Significance level: * $10 \%$, ${ }^{*} 5 \%$. Robust standard errors in parentheses.

Note: Abbreviations are explained in Section "Methodology and Data".

Source: authors' calculations.

The first two columns examine the association between flexicurity components and LP growth. The obtained estimations are in line with previously presented empirical studies (see Section 3) and are similar across both model specifications and both fixed 
and random effects, confirming the robustness of our results. On overall, regression estimates suggest a negative association between EPL strictness and LP, yet regression estimates are statistically insignificant, probably due to low variation in EPL index during the studied period. Nonetheless, results may potentially indicate that rigid employment regulations could by increasing the hiring costs and decreasing flexibility of labour market slow the flow of labour resources into new high-productivity firms or sectors or encourage shirking by employees (see OECD, 2007). A negative association can be also observed between expenditures for PLMPs and LP growth (statistically significant only in the random effects model specification). This signifies that generous labour market policies and thereby replacement rates may reduce work effort of existing employees due to lower cost of being fired or due to an increase in the duration of unemployment spells, causing the loss of human capital (see OECD, 2007). On the other hand, ALMPs and participation in LLL positively relate to the LP growth. Both policies contribute to the enhancement of workers' skills and knowledge and hence increase the stock of human capital with positive effect on productivity.

The last two columns present regression coefficients on relationship between flexicurity and TFP growth. The direction of the relation remains the same as in the first set of models, confirming the robustness of our findings. As can be seen, association between productivity growth and EPL index remains statistically insignificant. On the contrary, expenditures for ALMPs and participation in LLL have a statistically significant positive relationship with TFP growth, as an increase in ALMPs expenditures (or participation rate in LLL) for $1 \%$, increases TFP growth for approximately 1.1 percentage points (0.8 percentage points), ceteris paribus, when not including control for years effect. These regression estimates therefore confirm that higher investments in programs aimed at skill and knowledge improvement may increase productivity growth. Regression estimates for PLMPs, similarly as in the previous models, point on the negative relation with TFP growth (significant when including random effects), confirming detrimental effects of passive policies.

\section{Conclusions}

The paper examines the issue of flexicurity in the EU Member States and studies the association between flexicurity policy components and labour and total factor productivity growth. As flexicurity policy elements present complex entities, which are difficult to measure and compare between countries, we focus on four representative labour market institutions, one for each flexicurity component (i.e. EPL index, participation in LLL programs and expenditures for ALMPs and PLMPs), for 20 EU Member States over the 1991-2008 period.

Our econometric results confirm the importance of further development of flexicurity approach for productivity. Namely, panel regression estimates suggest that expenditures for ALMPs and participation in LLL positively relate to labour and total factor productivity growth. This implies that enhancement of workers' skills knowledge can result in an 
increase of the stock of human capital and stimulate productivity. On the other hand, EPL index and PLMPs variables give negative correlations (some estimates were statistically insignificant, though), showing that this could, on the one hand, demotivate workers and by that decrease their work effort and, on the other, slow the movement of labour resources into more productive sectors or firms, thereby decreasing the productivity. To conclude, based on our findings we can confirm that balanced flexicurity policies are of a special importance for further development of European labour markets and economies. This suggests that the European countries should continue with their unique path towards flexibilisation of employment regulation, simultaneously enhancing the security system and, most importantly, to develop comprehensive strategies of LLL and effective active employment policies together with conditions for their implementation.

At this point it should be noted that our analysis of the association between flexicurity policies and measures of productivity should present an introduction to a more comprehensive study on this issue. Problems that remain arise from the lack of a common definition and indicator of flexicurity and difficulties with obtaining reliable measures of development of LLL programmes, especially among NMS, and alternative measure of EPL rigidity. From the methodological point of view, panel regression analysis could suffer from the potential endogeneity and omission related biases - consequently, we cannot adequately define the direction of causality between flexicurity components and productivity, but merely their associations. In order to solve these problems, further detailed analyses are needed.

\section{References}

Acemoglu, D., Shimer, R. (1999), "Efficient Unemployment Insurance." Journal of Political Economy, Vol. 107, No. 5, pp. 893-928.

Acemoglu, D., Shimer, R. (2000), "Productivity Gains from Unemployment Insurance." European Economic Review, Vol. 44, No. 7, pp. 1195-1224.

Algan, Y., Cahuc, P. (2006), "Civic Attitudes and the Design of Labour Market Institutions: Which Countries Can Implement the Danish Flexicurity Model?" CEPR Discussion Papers, No. 5489.

Autor, D., Kerr, W. R., Kugler, A. D. (2007), "Do Employment Protections Reduce Productivity? Evidence from U.S. States." NBER Working Paper, No. 12860.

Bartelsman, E., Scarpetta, S., Schivardi, F. (2005), "Comparative Analysis of Firm Demographics and Survival: Evidence from Micro-level Sources in OECD countries." Industrial and Corporate Change, Vol. 14, No. 3, pp. 365-391.

Bassanini, A., Venn, D. (2008), "Assessing the Impact of Labour Market Policies on Productivity: A Difference-in-Differences Approach." International Productivity Monitor, Vol. 17, pp. 3-15.

Bassanini, A., Nunziata, L., Venn, D. (2009), "Job Protection Legislation and Productivity Growth in OECD Countries.” Economic Policy, Vol. 24, No. 04, pp. 349-402.

Belot, M., Boone, J., van Ours, J. (2007), "Welfare-Improving Employment Protection." Economica, Vol. 74, No. 295, pp. 381-396.

Bishop, J. (1994), "The Impact of Previous Training on Productivity and Wages," in Bishop, J., ed., Training and the Private Sector. Cambridge, MA: National Bureau of Economic Research, pp. 161-200. 
Black, S. E., Lynch, L. M. (1996), "Human-Capital Investments and Productivity." The American Economic Review, Vol. 86, No. 2, pp. 263-267.

Bredgaard, T., Larsen, F. (2007), "Comparing Flexicurity in Denmark and Japan." Centre for Labour Market Research, Aalborg University.

Calmfors, L. (1994), "Active Labour Market Policy and Unemployment - A Framework for the Analysis of Crucial Design Features". OECD Economic Studies, No. 22.

Cingano, F., Leonardi, M., Messina, J., Pica, G. (2010), "The Effects of Employment Protection Legislation and Financial Market Imperfections on Investment: Evidence from a Firm-level Panel of EU Countries." Economic Policy, Vol. 25, No. 61, pp. 117-163.

Conference Board (2011), "Data and Analysis." Available at http://www.conference-board.org/data/ (accessed on 10 April, 2011).

Council of the EU (2003), "Council Decision of 22 July 2003 on Guidelines for the Employment Policies of the Member States." Official Journal of the European Union, L 197, 5/8/2003, pp. 13-22.

De Groot, A. J., Elhorst, P. J. (2010), "Labour Market Effects of Flexicurity From a Regional Perspective." Tijdschrift voor economische en sociale geografie, Vol. 101, No. 4, pp. 392-408.

Dearden, L., Reed, H., Van Reenen, J. (2006), "The Impact of Training on Productivity and Wages: Evidence from British Panel Data." Oxford Bulletin of Economics and Statistics, Vol. 68, No. 4, pp. 397-421.

Dolenc, P., Vodopivec, M. (2005), "Does Work Pay in Slovenia?" Financial Theory and Practice, Vol. 29, No. 4, pp. 341-362.

European Commission (2007a), Employment in Europe 2007. Luxembourg: Office for Official Publications of the European Communities.

European Commission (2007b), Towards Common Principles of Flexicurity. Luxembourg: Office for Official Publications of the European Communities.

European Expert Group on Flexicurity (2007), Flexicurity Pathways: Turning Hurdles into Stepping Stones. Brussels: European Commission.

Eurostat (2011), "Statistics Database." Available at http://epp.eurostat.ec.europa.eu/eurostat (accessed on 2 April, 2011).

Hopenhayn, H., Rogerson, R. (1993), “Job Turnover and Policy Evaluation: A General Equilibrium Analysis.” The Journal of Political Economy, Vol. 101, No. 5, pp. 915-938.

Ichino, A., Riphahn, R. T. (2005), "The Effect of Employment Protection on Worker Effort: Absenteeism During and After Probation." Journal of the European Economic Association, Vol. 3, No. 1, pp. 120-143.

Jerman, M., Kavčič, S., Kavčič, B. (2010), "The Significance of Intangibles: A Comparative Analysis between Croatia, Slovenia, Czech Republic, Germany and the USA." Economic Research, Vol. 23, No. 2, pp. 60-69.

Keune, M., Jepsen, M. (2007), "Not Balanced and Hardly New the European Commission's Quest for Flexicurity." ETUI-RECHS Working paper, No. 1.

Koeniger, W. (2005), "Dismissal Costs and Innovation." Economics Letters, Vol. 88, No. 1, pp. 79-84.

Laporšek, S., Dolenc, P. (2012), "Do Flexicurity Policies Affect Labour Market Outcomes? An Analysis of EU Countries." The Croatian Journal of Social Policy, Vol. 19, No. 2, pp. 107-130.

Machin, S., Vignoles, A. (2001), The Economic Benefits of Training to the Individual, the Firm and the Economy: The Key Issues. London: Cabinet Office.

Madsen, P. K. (2007), "Flexicurity: A New Perspective on Labour Markets and Welfare States in Europe." Tilburg Law Review - Journal of International and Comparative Law, Vol. 14, No. 1\&2, pp. 57-79.

Marimon, R., Zilibotti, F. (1999), "Unemployment vs. Mismatch of Talents: Reconsidering Unemployment Benefits." The Economic Journal, Vol. 109, No. 455, pp. 266-291. 
Micco, A., Pages, C. (2006), "The Economic Effects of Employment Protection: Evidence from International Industry-Level Data." IZA Discussion Paper, No. 2433.

Muravyev, A. (2010), "Evolution of Employment Protection Legislation in the USSR, CIS and Baltic States, 1985-2009." IZA Discussion Papers, No. 5365.

Nickell, W. (2006), "The CEP-OECD Institutions Data Set (1960-2004)." Available at http://hdl.handle. net/1902.1/13555 UNF:3:A8ghQ3fq7k4yYPdFInkfkw (accessed on 15 January, 2012).

Nickell, S., Layard, R. (1999), "Labor Market Institutions and Economic Performance," in Ashenfelter, O., Card, D., eds., Handbook of Labor Economics, Elsevier, pp. 3029-3084.

OECD (1999), Employment Outlook 1999. Paris: OECD.

OECD (2007), OECD Employment Outlook 2007. Paris: OECD.

OECD (2011), "OECD Indicators of Employment Protection." Available at http://www.oecd.org/ employmentprotection (accessed on 2 April, 2011).

OECD.Stat (2011), "OECD.Stat Extracts." Available at http://stats.oecd.org/Index.aspx (accessed on 10 April, 2011).

Parello, C. P. (2011), "Labor Market Rigidity and Productivity Growth in a Model of Innovation-driven Growth." Economic Modelling, Vol. 28, No. 3, pp. 1058-1067.

Poschke, M. (2009), "Employment Protection, Firm Selection, and Growth." Journal of Monetary Economics, Vol. 56, No. 8, pp. 1074-1085.

Saint-Paul, G. (1997), "Is Labour Rigidity Harming Europe's Competitiveness? The Effect of Job Protection on the Pattern of Trade and Welfare." European Economic Review, Vol. 41, No. 3-5, pp. 499-506.

Saint-Paul, G. (2002), "Employment Protection, International Specialization, and Innovation." European Economic Review, Vol. 46, No. 2, pp. 375-395.

Scarpetta, S., Tressel, T. (2004), "Boosting Productivity via Innovation and Adoption of New Technologies: Any Role for Labour Market Institutions." World Bank Working Paper, No. 3273.

Soskice, D. (1997), "German Technology Policy, Innovation, and National Institutional Frameworks." Industry and Innovation, Vol. 4, No. 1, pp. 75-96.

Stubelj, I. (2010), "Valuation of Slovene Publicly Traded Companies with a Valuation Model Based on Expected Earnings and Growth Opportunities." Managing Global Transitions, Vol. 8, No. 1, pp. 23-47.

Visser, J. (2011), "ICTWSS: Database on Institutional Characteristics of Trade Unions, Wage Setting, State Intervention and Social Pacts in 34 countries between1960 and 2007." Available at http:// www.uva-aias.net/208 (accessed on 15 January, 2012).

Vodopivec, M., Dolenc, P., Vodopivec, M., Balde, A. (2007), Mobilnost dela in fleksibilnost sistema plač (Labour Mobility and Wage Flexibility). Koper: Fakulteta za management Koper.

Wilthagen, T., Tros, F. (2004), "The Concept of 'Flexicurity': A New Approach to Regulating Employment and Labour Markets." Transfer: European Review of Labour and Research, Vol. 10, No. 2, pp. 166-186.

Wooldridge, J. M. (2002), Econometric Analysis of Cross Section and Panel Data. Cambridge: The MIT Press. 